\title{
Investigation of hydrogeochemical properties of the Hüdai (Afyon-Sandıklı) geothermal systems, SW Turkey
}

\author{
Selma (Altinkale) Demer ${ }^{1, *}$, Ümit Memiş ${ }^{1}$ and Nevzat Özgür ${ }^{2}$ \\ ${ }^{1}$ Research and Application Center for Geothermal Energy, Groundwater and Mineral Resources, \\ Süleyman Demirel University, 32260, Isparta, Turkey. \\ ${ }^{2}$ Department of Geological Engineering, Süleyman Demirel University, 32260, Isparta, Turkey. \\ *Corresponding author.e-mail: selmademer@sdu.edu.tr
}

\begin{abstract}
Sandıklı-Hüdai geothermal field is one of the geothermal systems in Afyon and environ, located approximately $40 \mathrm{~km}$ southwest of Afyon. The study area consists of volcanic, sedimentary and metamorphic rocks. Kestel greenschist formation of Paleozoic age forms the basement rock in the area while quartzite which is a member of the Kestel greenschist formation serves as the reservoir rock of Sandıkl-Hüdai geothermal system. Geothermal waters from the study area are classified as $\mathrm{Na}-\mathrm{SO}_{4}-\mathrm{HCO}_{3}$ type waters. The waters plot along $\mathrm{SO}_{4}-\mathrm{HCO}_{3}$ end of the $\mathrm{Cl}-\mathrm{SO}_{4}-\mathrm{HCO}_{3}$ triangle diagram suggesting same origin for the geothermal waters. $\delta^{18} \mathrm{O}$ and $\delta \mathrm{D}$ isotope ratios of the Sandikl waters plot along the continental meteoric water line, indicating meteoric waters that were unaffected by evaporation. The tritium values imply that the fluids were deep circulating and recharged from older waters. Furthermore, oversaturation of the geothermal fluids with quartz confirms these findings showing long time residence of these groundwaters.
\end{abstract}

\section{Introduction}

The growth and development of countries is directly proportional to their energy needs and consumption. With approximately $90 \%$ of world's energy consumption being supplied by fossil fuels, finding alternative energy sources have become indispensable due to possible depletion of fossil energy sources in the nearest future as well as expensive exploration of new reserves and environmental pollution resulting from these sources. Geothermal energy is an important alternative energy source because it is renewable and environmental friendly considering its low carbon dioxide emission rate while not counting its cost effectiveness in the long term.
There are four geothermal fields within Afyon province namely, Ömer-Gecek, Gazligöl, HeybeliKaraburun geothermal fields and Sandıklı geothermal field, which is the investigated area for this study. Sandıklı-Hüdai geothermal field is located approximately $40 \mathrm{~km}$ southwest of Afyon, and typically used in direct-use applications such as in health, greenhouse activities and district heating.

Several studies on geology, hydrogeology along with hydrogeochemical properties for geothermal exploration and exploitation of the region have been conducted by many researchers including Karamanderesi (1972); Öngür (1973); Öztaş (1989); Afşin (1991); Mutlu (1996); Gürsu and Göncüoğlu (2005); Karamanderesi (2008); Özpınar (2008). However, this investigation examined

Keywords. Hydrogeochemistry; geothermal water; isotope; Sandıklı; Hüdai; Turkey. 
hydrogeochemical properties of geothermal fluids using hydrogeochemical and isotopic data while taking previous studies into consideration.

\section{Materials and methods}

General Directorate of Mineral Research and Exploration (MTA) and private organizations drilled 12 boreholes in the study area with the depth of these wells ranging from 50-750 m. During the field exercise, about 5 samples from geothermal wells were collected for further analysis in the laboratory and the sampling points were selected to represent the overall physical and chemical properties of the waters in the area. The sample points are used in balneological purposes, greenhouse activities and district heating in Sandıklı-Hüdai geothermal field. The anion and cation samples were filtered using $0.45 \mu \mathrm{m}$ filter papers while polypropylene bottles were used to collect samples for anion, cation and isotope analysis. The samples for cation analysis were acidified with suprapure $\mathrm{HNO}_{3}$ but that of anion were not and later sent to the laboratory preserved at $+4^{\circ} \mathrm{C}$.

In situ parameters such as temperature ( $\mathrm{T})$, hydrogen ion activity $(\mathrm{pH})$ and electrical conductivity (EC) were measured on the field using portable devices while alkalinity measurement was done by titrimetric method. Hydrogeochemical analysis of the samples was carried out using standard method (APHA-AWWA-WEF 2005) at Suleyman Demirel University, Research and Application Center for Geothermal Energy, Groundwater and Mineral Resources by ICP-OES and ion chromatography. Although no precision and accuracy tests were carried out for the analyzed results, the results are considered reliable owing to the fact that load-balance rate of the analyzed waters are generally less than $5 \%$ (table 1). Stable isotope analysis $\left(\delta^{2} \mathrm{H}\right.$ and $\left.\delta^{18} \mathrm{O}\right)$ by mass spectrometer and tritium $\left({ }^{3} \mathrm{H}\right)$ analysis were determined using liquid scintillation counting method at the Neuherberg Hydrology Institute, Germany. Hydrogeochemical analysis results were evaluated by utilizing AquaChem v.3.7 (Calmbach 1999) and SOLMINEQ.88 PC/SHELL (Kharaka et al. 1988) computer programs.

\section{Geological settings}

The study area is characterized with intense hydrothermal alteration and the geothermal system can be associated with neo-tectonic period tectonism and active volcanism. Miocene aged Sandiklı volcanism serves as the source of heat for the Hüdai geothermal system. Trachyte, andesite, trachyandesite, latite basalt, phonolite, tephrite type alkaline and calc-alkaline lavas, tuffs and ignimbrites were formed in different phases during Miocene volcanism in Sandiklı region (Karamanderesi 2008). Sandiklı formation consists of Upper Miocene aged Akin tuff, Sandıklı and Pliocene aged Hamamçayı members (Afşin 1991). Koçgazi phyllite member, which constitutes impermeable basement rock of Afyon-Sandıklı geothermal system, is composed of beige, brownish coloured beige, fine grained sandstone with very low metamorphism, black and brown-purple coloured siltstone and metabasic sills intercalated with these in patches. Lower Cambrian aged Hüdai formation consists mostly of quartzites and are in places intercalated with schists. The quartzites are medium-thick and cross bedded, light grey, rust and pink coloured and laminated. Approximate thickness of a unit is about 400-600 m. Hüdai formation which serves as the reservoir rocks of Afyon-Sandikl geothermal system is characterized mainly by synclinal type folds and secondary porosity. The Hüdai formation is mostly conformable over phyllites and has a transitional contact relation with overlying Çaltepe formation. Seydişehir formation, which forms the cover rock of geothermal system, is composed of shale and quartz sandstone intercalations. Thin, variegated and nodular limestone bands are observed at the lower most part of the sequence (Afşin 1991; Özgül et al. 1991; Günay et al. 1995; Gürsu and Göncüoğlu 2005). Upper Triassic-Lower Jurassic aged Karatepe formation consists mainly of conglomerate, sandstone and siltstones. Lower Jurassic aged Derealanı formation starts with marly sandstone and passes upward to sandy, silty and argillaceous limestones with sandy limestone intercalation. Upper JurassicLower Cretaceous aged Akdağ formation is made up of nearly massive brachiated limestone and passes upward to limestone and dolomitic limestone with an increase in chert layers (Afşin 1991; Özpınar 2008; figure 1).

\section{Hydrogeochemistry}

Hydrogeochemistry is an indispensable unit of hydrogeological studies because it aids in the determination of chemical properties as well as the overall qualities of groundwater, including their genesis and relationship with surface and rain waters. Therefore, it is an important part of geothermal research program (Tarcan 2002). Five geothermal fluid samples were taken from Sandıklı geothermal field. In situ and hydrogeochemical analysis of the water samples from the study area are given in table 1. 
Table 1. Results of in situ measurements and hydrogeochemical analyses of the water samples from the SandiklvHüdai geothermal field (Memiş 2010; Demer et al. 2011).

\begin{tabular}{|c|c|c|c|c|c|c|c|c|}
\hline Sample & AFS-6 & AFS-9 & AFS-11 & AFS-12 & AFS-15 & WHO 2006 & EPA 2003 & TS266 2005 \\
\hline $\mathrm{T}\left({ }^{\circ} \mathrm{C}\right)$ & 69.0 & 69.0 & 73.6 & 73.5 & 75.0 & - & - & - \\
\hline $\mathrm{pH}$ & 6.45 & 6.52 & 6.48 & 6.47 & 7.26 & $6.5-8.5$ & $6.5-8.5$ & $6.5-9.5$ \\
\hline $\mathrm{EC}(\mu \mathrm{S} / \mathrm{cm})$ & 1943 & 1982 & 2300 & 2250 & 2020 & - & - & - \\
\hline $\mathrm{O}_{2}(\mathrm{mg} / \mathrm{l})$ & 5.0 & 4.4 & 2.5 & 3.1 & 4.3 & - & - & - \\
\hline $\mathrm{Na}^{+}(\mathrm{mg} / \mathrm{l})$ & 208.30 & 205.90 & 276.00 & 249.80 & 245.40 & 200 & - & 200 \\
\hline $\mathrm{K}^{+}(\mathrm{mg} / \mathrm{l})$ & 30.14 & 34.89 & 57.92 & 46.36 & 47.97 & - & - & - \\
\hline $\mathrm{Mg}^{++}(\mathrm{mg} / \mathrm{l})$ & 21.26 & 20.56 & 26.82 & 26.92 & 27.45 & - & - & - \\
\hline $\mathrm{Ca}^{++}(\mathrm{mg} / \mathrm{l})$ & 135.20 & 130.30 & 150.82 & 155.48 & 150.10 & - & - & - \\
\hline $\mathrm{SiO}_{2}(\mathrm{mg} / \mathrm{l})$ & 63.32 & 64.77 & 68.62 & 68.32 & 76.80 & - & - & - \\
\hline $\mathrm{Li}(\mathrm{mg} / \mathrm{l})$ & 0.23 & 0.19 & 0.30 & 0.28 & 0.30 & - & - & - \\
\hline $\mathrm{Pb}(\mathrm{mg} / \mathrm{l})$ & $<0.01$ & $<0.01$ & 0.05 & 0.05 & $<0.01$ & 0.01 & - & 0.01 \\
\hline $\mathrm{Zn}(\mathrm{mg} / \mathrm{l})$ & $<0.01$ & $<0.01$ & 0.05 & 0.06 & $<0.01$ & 3 & 5 & 5 \\
\hline $\mathrm{Cu}(\mathrm{mg} / \mathrm{l})$ & $<0.01$ & 0.06 & 0.04 & 0.04 & 0.06 & 2 & 1.3 & 2 \\
\hline $\mathrm{Al}(\mathrm{mg} / \mathrm{l})$ & $<0.01$ & $<0.01$ & $<0.01$ & $<0.01$ & 0.44 & 0.2 & 0.2 & 0.2 \\
\hline $\mathrm{Fe}(\mathrm{mg} / \mathrm{l})$ & 0.34 & 0.14 & 0.22 & 0.35 & 0.62 & 0.3 & 0.3 & 0.2 \\
\hline $\mathrm{Mn}(\mathrm{mg} / \mathrm{l})$ & 0.15 & 0.16 & 0.06 & 0.19 & 0.14 & 0.4 & 0.05 & 0.05 \\
\hline $\mathrm{Sr}(\mathrm{mg} / \mathrm{l})$ & 0.56 & 0.64 & 0.65 & 0.65 & 0.78 & - & - & - \\
\hline $\mathrm{Sb}(\mathrm{mg} / \mathrm{l})$ & $<0.01$ & $<0.01$ & $<0.01$ & $<0.01$ & $<0.01$ & 0.005 & - & 0.005 \\
\hline As (mg/l) & 0.45 & 0.24 & 0.58 & 0.54 & 0.60 & 0.01 & 0.01 & 0.01 \\
\hline $\mathrm{B}(\mathrm{mg} / \mathrm{l})$ & 0.42 & 1.25 & 0.72 & 0.60 & 0.72 & 0.5 & 1 & 1 \\
\hline $\mathrm{Ba}(\mathrm{mg} / \mathrm{l})$ & 0.07 & 0.04 & 0.03 & 0.03 & 0.07 & 0.7 & 2 & - \\
\hline $\mathrm{Tl}(\mathrm{mg} / \mathrm{l})$ & 0.03 & 0.06 & 0.06 & 0.06 & 0.02 & - & - & - \\
\hline $\mathrm{NO}_{3}^{-}(\mathrm{mg} / \mathrm{l})$ & 23.08 & 1.11 & 11.30 & 1.23 & 0.98 & 50 & - & 50 \\
\hline $\mathrm{NO}_{2}^{-}(\mathrm{mg} / \mathrm{l})$ & $<0.01$ & $<0.01$ & $<0.01$ & $<0.01$ & $<0.01$ & 0.2 & - & 0.5 \\
\hline $\mathrm{HCO}_{3}^{-}(\mathrm{mg} / \mathrm{l})$ & 518.5 & 561.20 & 579.50 & 573.40 & 481.90 & - & - & - \\
\hline $\mathrm{PO}_{4}(\mathrm{mg} / \mathrm{l})$ & $<0.01$ & $<0.01$ & $<0.01$ & $<0.01$ & $<0.01$ & - & - & - \\
\hline $\mathrm{Cl}^{-}(\mathrm{mg} / \mathrm{l})$ & 84.83 & 101.15 & 100.88 & 93.60 & 109.51 & 250 & 250 & 250 \\
\hline $\mathrm{SO}_{4}^{2-}(\mathrm{mg} / \mathrm{l})$ & 441.86 & 506.53 & 533.88 & 517.88 & 629.49 & 250 & 250 & 250 \\
\hline $\mathrm{F}^{-}(\mathrm{mg} / \mathrm{l})$ & 3.83 & 3.91 & 3.77 & 3.35 & 4.85 & 1.5 & 2 & 1.5 \\
\hline$\%$ ion balance & 4.6 & 5.1 & 0.6 & 1.5 & 4.5 & & & \\
\hline $\mathrm{SI}_{\mathrm{c}}$ (calcite) & 0.193 & 0.201 & 0.272 & 0.275 & 0.951 & & & \\
\hline $\mathrm{SI}_{\mathrm{d}}$ (dolomite) & 1.451 & 1.399 & 1.648 & 1.642 & 3.031 & & & \\
\hline $\mathrm{SI}_{\mathrm{q}}$ (quartz) & 0.436 & 0.513 & 0.487 & 0.486 & 0.504 & & & \\
\hline$\delta^{18} \mathrm{O}$ & -10.34 & -10.47 & - & - & -10.66 & & & \\
\hline$\delta \mathrm{D}$ & -72.15 & -73.90 & - & - & -74.30 & & & \\
\hline${ }^{3} \mathrm{H}$ & - & $<1.00$ & - & - & $<0.70$ & & & \\
\hline
\end{tabular}

Temperature measurements of the geothermal fluid samples are between $69^{\circ}$ and $75^{\circ} \mathrm{C}$, and EC values are between 1943 and $2300 \mu \mathrm{S} / \mathrm{cm}$. pH values of the fluids vary between 6.45 and 7.26 and generally show an acidic characteristic. Hydrogeochemical facies of the waters was evaluated by plotting the analyzed result on Piper's diagram. According to this diagram, the geothermal fluids are estimated to be $\mathrm{Na}-\mathrm{SO}_{4}-\mathrm{HCO}_{3}$ type exchange waters (figure 2). The Schoeller diagram suggests that the array of dominant ions of the geothermal fluids are $\mathrm{Na}+\mathrm{K}>\mathrm{Ca}>\mathrm{Mg}$ for the cations and $\mathrm{SO}_{4}>\mathrm{HCO}_{3}>\mathrm{Cl}$ for the anions (figure 3 ).

The main potential pollutants in geothermal waters are hydrogen sulphide $\left(\mathrm{H}_{2} \mathrm{~S}\right)$, arsenic (As), boron (B), mercury $(\mathrm{Hg})$ and other trace metals (e.g., lead $(\mathrm{Pb})$, cadmium $(\mathrm{Cd})$, iron $(\mathrm{Fe})$, zinc $(\mathrm{Zn})$ and manganese $(\mathrm{Mn})$ (Kristmannsdottir and Armannsson 2003; Baba 2004; Baba and Armannsson 2006). As, B and F contents are relatively high in Sandıklı-Hüdai geothermal waters. Arsenic is a common constituent in groundwater that affects human health adversely even at level as low as $10 \mu \mathrm{g} / \mathrm{l}$ (WHO 1993; Bhattacharya et al. 2002). Wide varieties of adverse health effects, including skin and internal cancers, cardiovascular and neurological effects, have been attributed to chronic Arsenic exposure, primarily from drinking water (NRC 1999). Arsenic concentrations of thermal waters from the study area vary between 0.24 and 

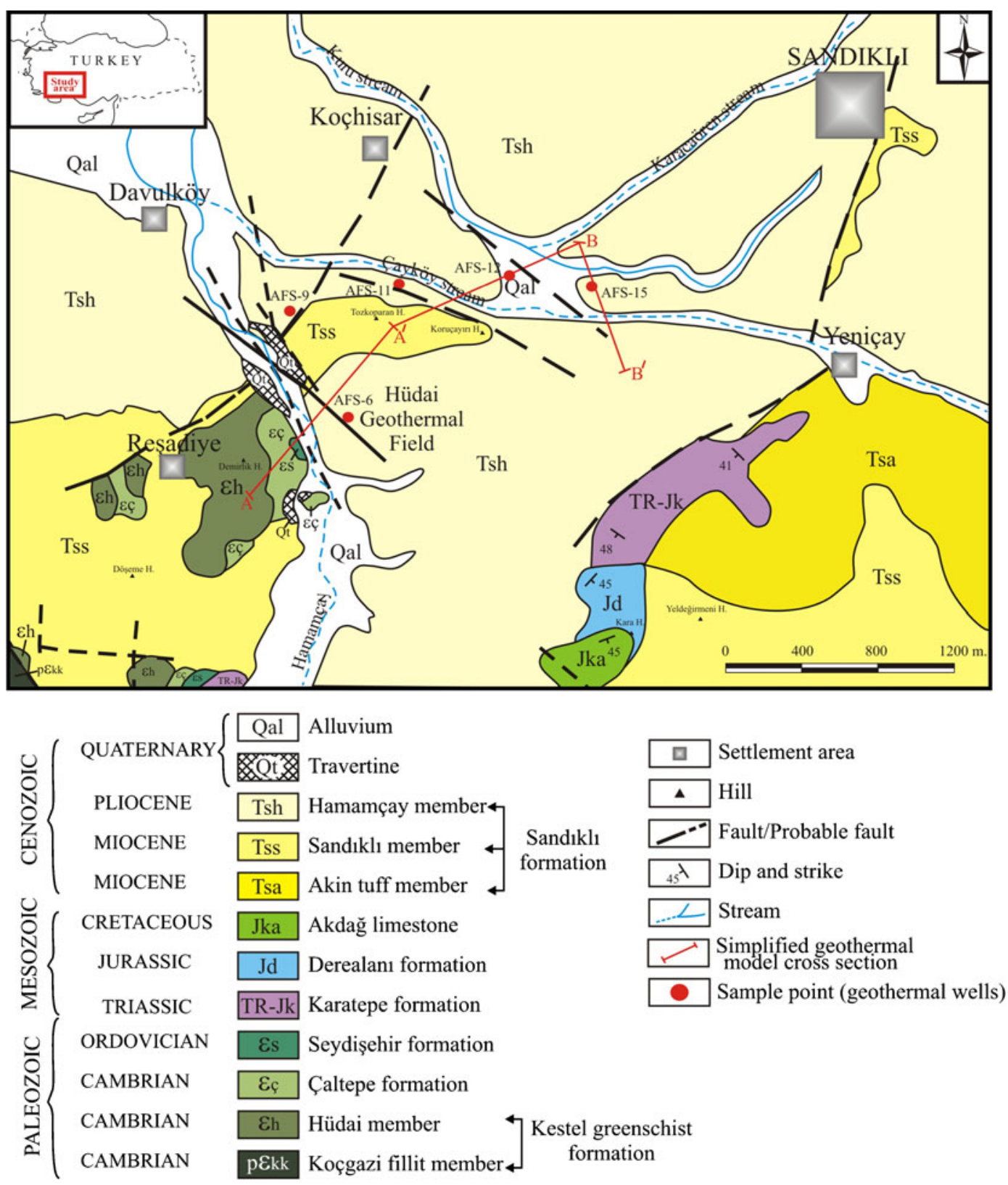

Figure 1. Geological map of Afyon-Sandıklı Hüdai geothermal field and environs (compiled from Öngür 1973; Afşin 1991; Memiş 2010) and sampling locations.

$0.60 \mathrm{mg} / \mathrm{l}$. These values for all the water samples exceeded the limit of $10 \mu \mathrm{g} / \mathrm{l}$ (EPA 2003; TS266 2005; WHO 2006) proposed for human consumption. Boron is important in very small concentration for normal growth of plants, but in high concentration it becomes toxic. As a general classification, boron concentrations of groundwater exceeding $1 \mathrm{mg} / \mathrm{l}$ are harmful for plants (Richards 1954). Boron concentrations of thermal waters in the study area are from 0.42 to $1.25 \mathrm{mg} / \mathrm{l}$. These values are higher than the safe levels required for drinking and irrigation purposes. Fluorine concentrations of Sandiklı-Hüdai thermal waters vary between 3.35 and $4.85 \mathrm{mg} / \mathrm{l}$, and these exceed the standard values proposed by WHO (2006); EPA (2003); TS266 (2005). Consequently, the geothermal water in the region is harmful to both plants and animals, hence cannot be used for domestic purpose. In accordance with the result of the analysis, Na, Mn concentrations exceeded the tolerance limit. Sulfate concentration exceeds the tolerance limits (250 mg/l for WHO 2006; EPA 2003 and TS266 2005) in all samples. Fe ranges from 0.14 and $0.62 \mathrm{mg} / \mathrm{l}$ and slightly exceeds the drinking standard (table 1).

The distribution of the Sandikl geothermal waters on $\mathrm{Cl}-\mathrm{SO}_{4}-\mathrm{HCO}_{3}$ triangle diagram along $\mathrm{SO}_{4}-\mathrm{HCO}_{3}$ zone (figure 4) indicates that they are 


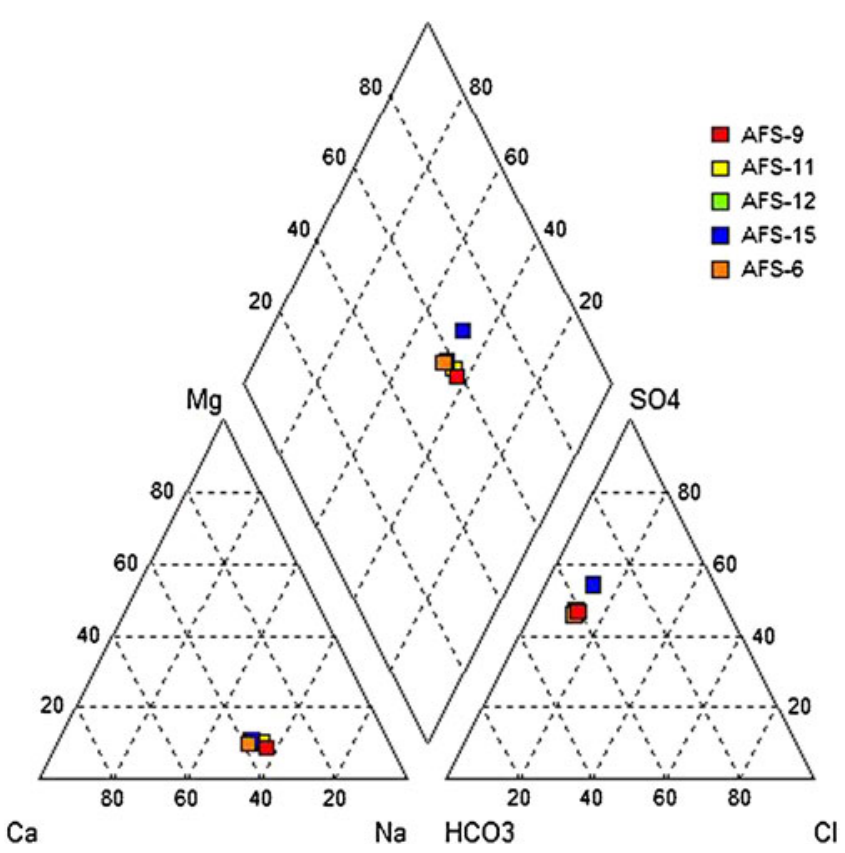

Figure 2. Distribution of the geothermal waters from Sandıklı-Hüdai geothermal field in Piper diagram.

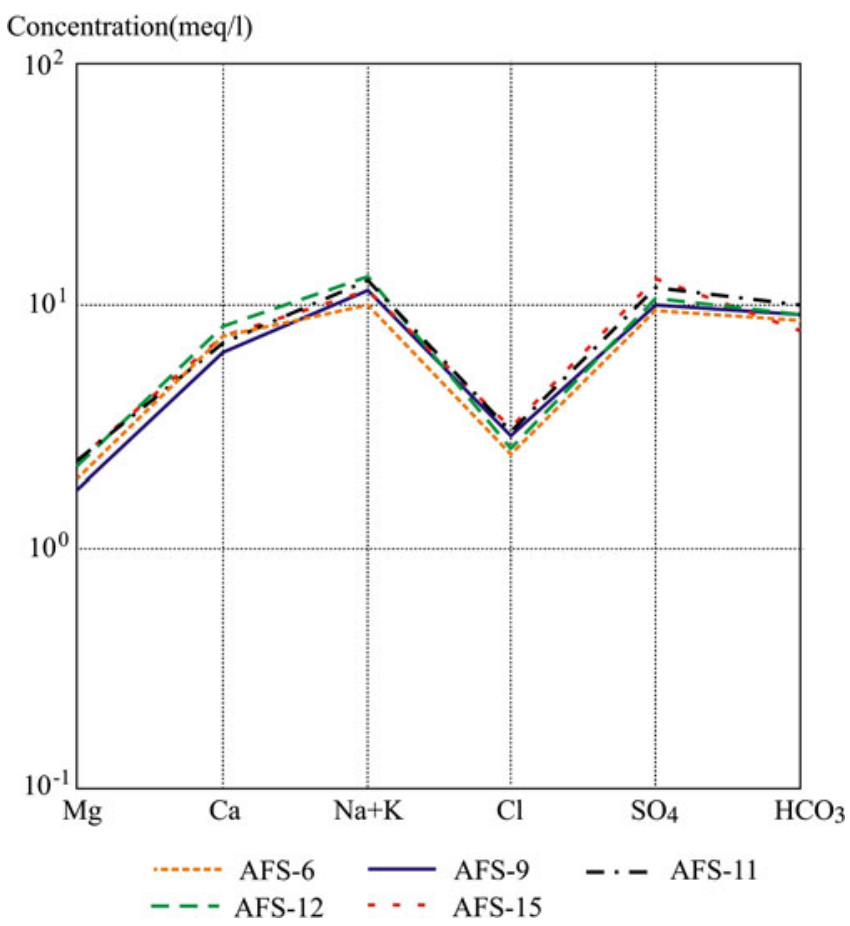

Figure 3. Distribution of the geothermal waters from Sandıklı-Hüdai geothermal field in Schoeller semi-logarithmic diagram.

of same origin and similar water. High sulfate content and low $\mathrm{pH}$ values in geothermal fluids could be from the oxidation of $\mathrm{H}_{2} \mathrm{~S}$ (equation 1) near

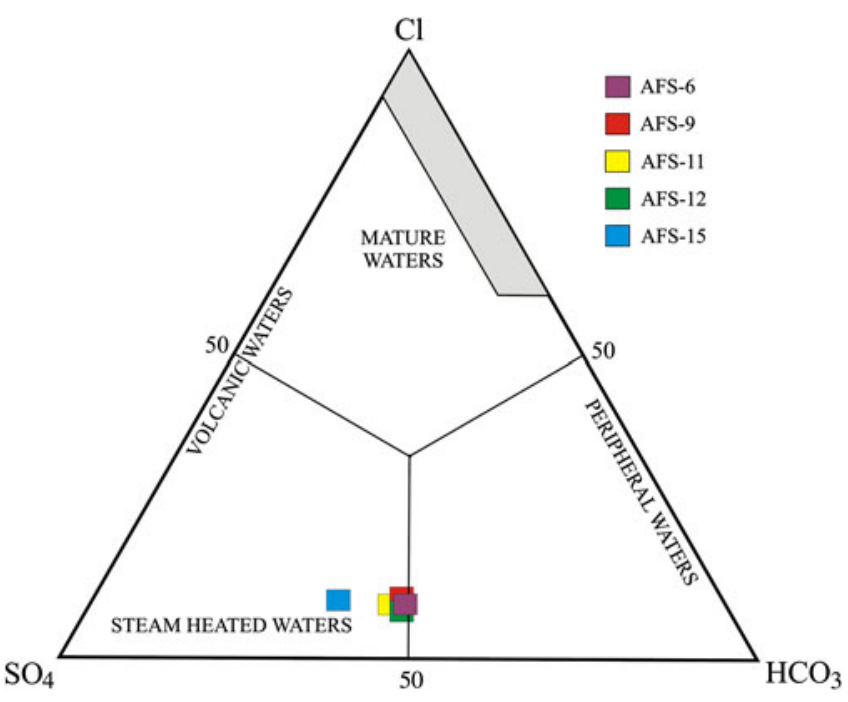

Figure 4. Distribution of the geothermal waters from the study area in $\mathrm{Cl}-\mathrm{SO}_{4}-\mathrm{HCO}_{3}$ triangular diagram (Giggenbach 1988).

surface and/or from the oxidation of pyrite $\left(\mathrm{FeS}_{2}\right)$ nodules in Seydişehir formation (equation 2).

$$
\begin{gathered}
\mathrm{H}_{2} \mathrm{~S}+4 \mathrm{H}_{2} \mathrm{O} \rightarrow \mathrm{SO}_{4}^{-2}+10 \mathrm{H}^{+}+8 \mathrm{e}^{-} \\
\mathrm{FeS}_{2}+7 / 2 \mathrm{O}_{2}+\mathrm{H}_{2} \mathrm{O}=>\mathrm{Fe}^{+2}+2 \mathrm{SO}_{4}^{-2}+2 \mathrm{H}^{+}
\end{gathered}
$$

The reservoir temperature of the geothermal waters in the study area was calculated using silica geothermometers and cation geothermometers. The quartz geothermometer produced reservoir temperature of about $110^{\circ}-120^{\circ} \mathrm{C}$ while chalcedony geothermometer gave an approximate temperature between $85^{\circ}$ and $100^{\circ} \mathrm{C}$. Based on chalcedony and quartz geothermometers, enthalpy-silica and enthalpy-chloride mixing models suggest that reservoir temperature of the geothermal fluids is between $108^{\circ}-134^{\circ} \mathrm{C}$ and $98^{\circ}-120^{\circ} \mathrm{C}$ respectively. However, the obtained reservoir temperature for Hüdai geothermal field is around $110^{\circ} \mathrm{C}$ (Memiş et al. 2010).

According to the simplified schematic model of Hüdai geothermal system (figure 5), Upper Cambrian-Middle Ordovician aged Seydişehir formation comprises of impermeable cover rocks. Lower Cambrian-Middle Ordovician aged Hüdai member which belongs to Paleozoic Kestel Greenschist formation makes up the hot water reservoirs and Koçgazi phyllite member of the same formation forms the impermeable basement rocks. In Hüdai geothermal field, meteoric waters percolate the fault zones and the permeable units to be heated by the deep magma chamber. Besang et al. (1977) and Ercan (1986) suggested that Sandiklı 


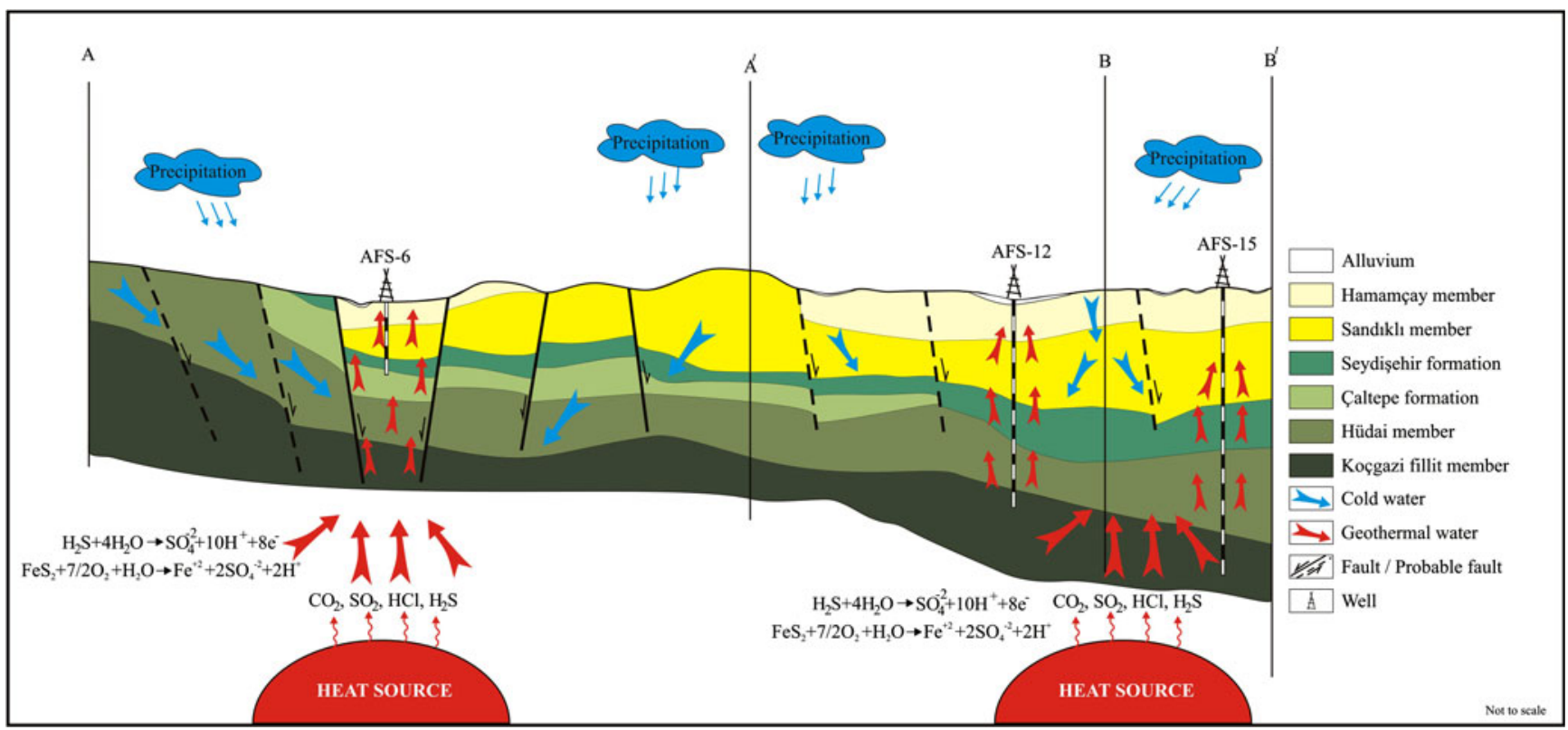

Figure 5. Simplified model of Sandıklı-Hüdai geothermal system (from Memiş 2010).

volcanics considered as the source of heat vary in composition from calc-alkaline to alkaline and their minimum $\mathrm{K} / \mathrm{Ar}$ age was determined as $14.75 \pm$ $0.3 \mathrm{my}$ and $8.0 \pm 0.6 \mathrm{my}$. The percolated waters reacted with the heated rocks resulting in waterrock interactions. Meteoric fluids are heated by the cooling magmatic melt and ascend to the surface due to their lower density, caused by convection cells. The magmatic volatiles such as $\mathrm{CO}_{2}$, $\mathrm{SO}_{2}, \mathrm{HCl}$ and $\mathrm{H}_{2} \mathrm{~S}$ reach the geothermal water reservoir making equilibrium to be established among altered rocks, gas components, and fluids (Hedenquist and Lowenstern 1994). The ascending fluids mostly contain $\mathrm{CO}_{2}, \mathrm{H}_{2} \mathrm{~S}$ and $\mathrm{HCl}$, thus the geothermal waters travel through the tectonic zones reaching the surface in the form of hot water springs with gases and vapours.

\section{Mineral saturation state}

Mineral equilibrium calculations are important in predicting precipitation processes during extraction and use of geothermal fluids. Therefore, the degree of mineral saturation in groundwater should be investigated. Saturation index (SI) indicates numerical deviation of equilibrium state in terms of dissolved minerals in water (Appello and Postma 1996; Drever 1996; Langmuir 1997). The saturation condition of a solution with respect to any mineral is classified as undersaturated when the saturation index is less than $0(\mathrm{SI}<0)$, saturated when $\mathrm{SI}=0$ and supersaturated when SI $>0$
(Stumm and Morgan 1981). Mineral saturation indices of hydrothermal minerals present in the reservoir of the geothermal system were calculated with SOLMINEQ.88 PC/SHELL (Kharaka et al. 1988) computer code. According to the results of equilibrium calculations, quartz, calcite and dolomite show saturation trends with increasing temperature (table 1). The geothermal fluid is saturated with quartz, because of the quartzitic reservoir rocks and long residence time within this reservoir. The fluid is saturated with calcite and dolomite due to its interaction with limestones and dolomitic formations en route to the surface.

\section{Isotope geochemistry}

In geothermal studies, natural isotopes of water such as $\delta^{18} \mathrm{O}, \delta^{2} \mathrm{H}$ are used in determining drainage basin and the origin of springs, water-reservoir rock relations, the temperature of reservoir rocks, relative age of water, and the degree of mixing of cold water with hot water (Bayram and Şimşek 2005). The biggest source of the groundwater in isotope cycle is from the oceans and its stable isotope concentration is constant. Isotope values of all other waters are measured with reference to SMOW (Standard Mean Ocean Water) whose $\delta$ value is assumed to be zero. Tritium atoms exist in nature in $1.10^{-15}$ ratios and its concentration in water is given as tritium unit (TU). One Tritium Unit (TU) is defined as the ratio of one tritium 


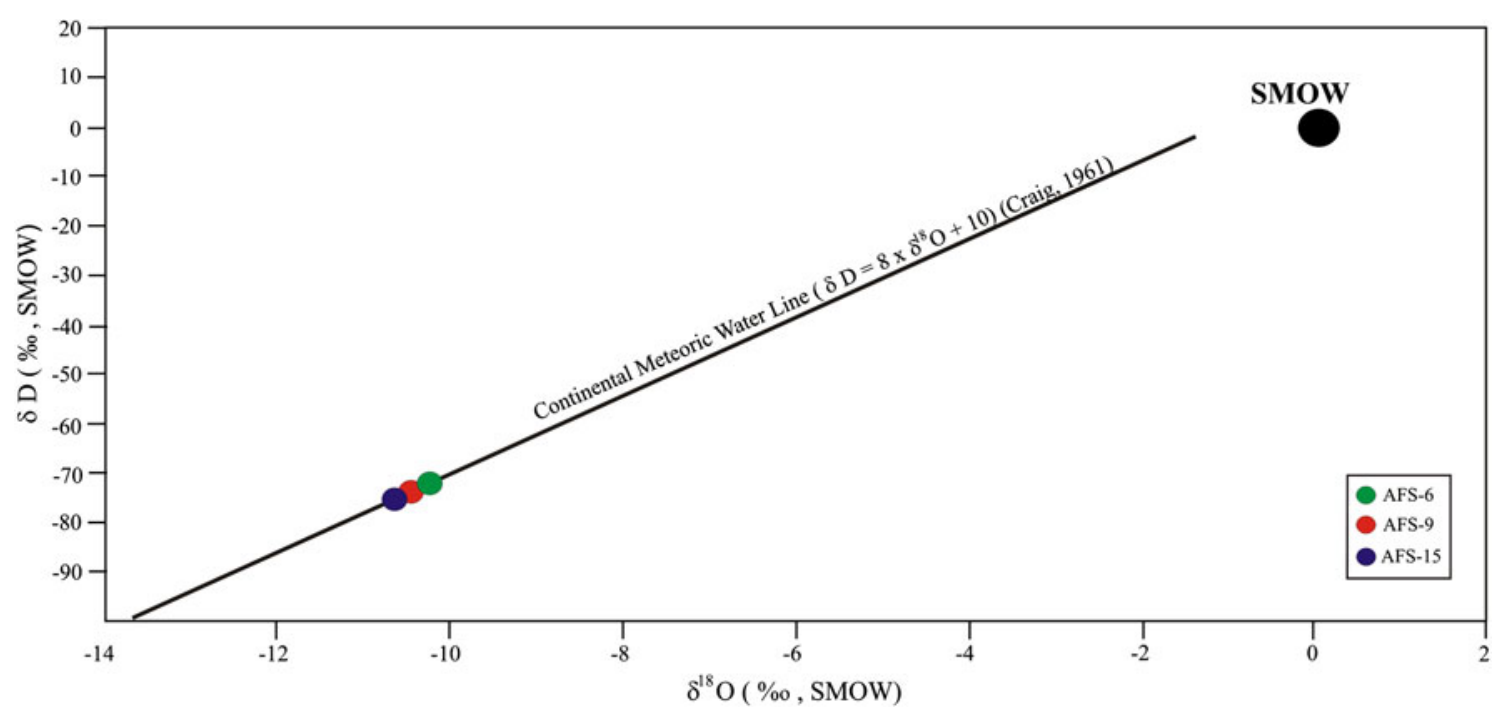

Figure 6. $\delta \mathrm{D}$ vs. $\delta^{18} \mathrm{O}$ plot of the groundwaters and geothermal waters in Sandıklı-Hüdai geothermal field (from Memiş 2010 and Demer et al. 2011).

atom to $10^{18}$ hydrogen atoms. Tritium are used in reservoir monitoring studies because an increase in the ${ }^{3} \mathrm{H}$ of geothermal discharges are indication of increasing dilution or of a rapid recharge by meteoric waters. The activity of tritium $\left({ }^{3} \mathrm{H}\right.$, halflife 12.43 years) in thermal waters provides a useful tracer to understand underground residence times. According to a compilation by Gat (1980), the tritium content of meteoric precipitation in the northern hemisphere has fluctuated widely from values less than 25 TU before 1953 up to more than 2200 TU in 1964 following the extensive testing of nuclear devices in the atmosphere. If a groundwater contains $1.1 \mathrm{TU}$, this indicates that it was recharged before the testing of nuclear devices in the atmosphere. To wit, it may be older than 1953 (Güleç and Mutlu 2002). Low tritium concentration in the geothermal waters $(<1 \mathrm{TU})$ suggests that the thermal aquifer is recharged by groundwaters with relatively long residence time ( $>55$ years), showing a deep groundwater circulation system in the area. The cold water aquifers, on the other hand, appear to have been recharged with a component of relatively younger precipitation.

Samples for isotope analysis were collected from the geothermal waters in the study area and Deuterium (D), Oxygen-18 $\left({ }^{18} \mathrm{O}\right)$ and Tritium $\left({ }^{3} \mathrm{H}\right)$ analyses were carried out on the samples. Results obtained from the analyses are presented in table 1 . $\delta^{18} \mathrm{O}$ and $\delta \mathrm{D}$ isotope ratios of the waters generally plot along the continental meteoric water line and represent meteoric waters that were unaffected by evaporation (figure 6 ). Low tritium values (table 1 ) of the geothermal fluid in the study area show that these waters were recharged by precipitations before nuclear bomb tests.

\section{Results}

Geothermal waters from Sandıklı-Hüdai geothermal area are suitable for greenhouse activities, space heating, and balneological purposes. However, some major ( $\mathrm{Na}$ and $\mathrm{SO}_{4}$, etc.) and secondary ion concentrations especially As, B and $\mathrm{F}$ exceed the tolerance limits in Sandıklı-Hüdai geothermal waters. Therefore, using the thermal waters as drinking and mineral water for curative purpose may have adverse effects on human health. All possible environmental effects of these trace elements should be identified and also minimized in order to reduce their impacts. The geothermal waters in the study area can be classified as $\mathrm{Na}-$ $\mathrm{SO}_{4}-\mathrm{HCO}_{3}$ type waters. High sulfate content in the geothermal fluid emanates from the oxidation of $\mathrm{H}_{2} \mathrm{~S}$ near the surface and/or from the oxidation of pyrite $\left(\mathrm{FeS}_{2}\right)$ nodules in Seydişehir formation. Reservoir temperature measured with several geothermometer methods is estimated to be $110^{\circ} \mathrm{C}$ in Hüdai geothermal field. The geothermal fluid is saturated with quartz according to saturation index calculations. This has, most likely, resulted from the fact that the reservoir rock is quartzite and the residence time in the reservoir is long. The ratio of $\delta^{18} \mathrm{O}$ and $\delta \mathrm{D}$ shows that the samples in the investigated area generally correspond with continental meteoric water line and represent meteoric waters that were unaffected by evaporation. 
Low tritium values of the geothermal fluid reveal that it is deep circulated water and recharged by old water.

\section{Acknowledgements}

The authors wish to thank Scientific Research Project unit of Süleyman Demirel University (project numbers: 1894-YL-09 and 2618-M-10), for the financial support. Dr Ö Elitok and O A Bello, Süleyman Demirel University, are appreciated for reviewing the manuscript.

\section{References}

Afşin M 1991 The hydrogeological investigation of Sandıklı (Afyon) Kuruçay plain and Hüdai thermal springs; $\mathrm{PhD}$ thesis, Ankara University, Graduate School of Natural and Applied Sciences, Ankara, 330p.

APHA-AWWA-WEF 2005 Standard methods for the examination of water and wastewater; 21st edn, In: American Public Health Association (eds) Eaton A D, Clesceri L S, Rice E W and Greenberg A E, Washington, DC.

Appello C A J and Postma D 1996 Geochemistry, groundwater and pollution; Balkema, Rotterdam, 536p.

Baba A 2004 Environmental impact of the utilization of a geothermal area; J. Istanbul Kültür University 1 33-38.

Baba A and Armannsson H 2006 Environmental impact of the utilization of geothermal areas; Energy Source Part B 1 267-278, doi: 10.1080/15567240500397943.

Bayram F and Şimşek Ş 2005 Hydrogeochemical and isotopic survey of Kütahya-Simav geothermal field; In: Proceedings, World Geothermal Congress, 24-29 April 2005, Antalya, Turkey, pp. 1-11.

Besang C, Eckhardt F J, Harre W, Kreuzer H and Müller P 1977 Radiometrische Altersbestimmungen an Neogenen Eruptivgesteinen der Turkei. Geol. Jahrb.; Reihe B. 25 $3-36$.

Bhattacharya P, Jacks G, Ahmed K M, Routh J and Khan A A 2002 Arsenic in groundwater of the Bengal Delta Plain Aquifers in Bangladesh; Bull. Environ. Contam. Toxicol. 69 538-545.

Calmbach L 1999 AquaChem Computer Code-Version 3.7: Aqueous geochemical analyses, plotting and modelling; Waterloo Hydrogeologic, Waterloo, Ontario, Canada, $184 \mathrm{p}$.

Craig 1961 Isotopic variations in meteoric waters; Science 133 1702-1703.

Demer S, Özgür N and Memiş Ü 2011 Hydrogeological, hydrogeochemical and isotope geochemical investigations of the Hüdai geothermal field at Sandıklı, Afyon; Süleyman Demirel University, Scientific Research Project, project number: 2618-M-10 (on going).

Drever J I 1996 The Geochemistry of Natural Waters, 3rd edn (New Jersey: Prentice Hall), 436p.

Ercan T 1986 Cenozoic volcanism of Central Anatolia; Bull. Min. Res. Exp. 107 119-141.

EPA (Environmental Protection Agency) 2003 List of drinking water contaminants and MCLs; National Primary Drinking Water Regulations, Washington DC.

Gat J R 1980 The isotopes of hydrogen and oxygen in precipitation; In: Handbook of Environmental Isotope
Geochemistry, The Terrestrial Environment (eds) Fritz $\mathrm{P}$ and Fontes J-Ch (Amsterdam: Elsevier) 1 21-48.

Giggenbach W F 1988 Geothermal Solute Equilibria. Derivation of $\mathrm{Na}-\mathrm{K}-\mathrm{Mg}-\mathrm{Ca}$ Geoindicators; Geochim. Cosmochim. Acta 52 2749-2765.

Güleç N and Mutlu H 2002 Isotope geochemistry in geothermal field. Application of Earth Science in geothermal; Summer School, Dokuz Eylul University, pp. 74-103.

Günay Y, Derman A S, Kozlu H, Göncüoğlu C M and Gül M A 1995 Stratigraphy of Lower Paleozoic in Southern Turkey; IGCP Project 351 - Early Paleozoic Evolution in NW Gondwana Excursion Guide Book, pp. 3-9.

Gürsu S and Göncüoğlu M C 2005 The geology and petrography of Late Neoproterozoic and Early Paleozoic units of Western Taurus (SW-Sandıklı, Afyon); Bull. Min. Res. Exp. 130 29-55.

Hedenquist J W and Lowenstern J B 1994 The role of magmas in the formation of hydrothermal ore deposits; Nature $370519-527$.

Karamanderesi İ H 1972 Afyon K24-b paftası detay jeoloji etüdü ve jeotermal alan olanakları hakkında rapor; MTA Rapor No. 5733.

Karamanderesi I H 2008 The geological and mineralogical evaluation of the Afyonkarahisar geothermal fields; In: Proceedings Conference of Thermal and Mining Waters (eds) Türker A E and Yıldız A, 24-25 April 2008, Afyonkarahisar, pp. 55-69.

Kharaka Y K, Gunter W D, Aggarwal P K, Perkins E H and Debraal J D 1988 SOLMINEQ.88: A computer program for geochemical modeling of water-rock interactions; U.S. Geol. Surv. Water Res. Inv. Rep. 88-4227, 420 p.

Kristmannsdottir H and Armannsson H 2003 Environmental aspects of geothermal energy utilization; Geothermics 32 $451-461$.

Langmuir D 1997 Aqueos Environmental Geochemistry (USA: Prentice-Hall Publication), 600p.

Memiş Ü 2010 Determination of hydrogeochemical features and investigation of trace element pollution of the Hüdai geothermal field in Sandıklı, Afyon (in Turkish); MSc thesis, Süleyman Demirel University, 64p.

Memiş Ü, Demer S and Özgür N 2010 Investigation of reservoir temperature of the Afyon-Sandıklı Hüdai geothermal system; Süleyman Demirel University, J. Nat. Appl. Sci. 14(3) 293-299.

Mutlu H 1996 Geochemical assesment of thermal waters from the Afyon geothermal area: Geothermometry applications and fluid-mineral equilibria; PhD thesis, Middle East Technical University, Graduate School of Natural and Applied Sciences, 169p.

NRC 1999 Arsenic in Drinking Waters; Subcommittee on Arsenic in Drinking Water, National Research Council, National Academy Press, 330p.

Öngür T 1973 Sandıklı (Afyon) jeotermal araştırma bölgesine ilişkin jeolojik durum ve jeotermal enerji olanakları; MTA Rapor No: 5520, Ankara.

Özgül N, Bölükbaşı S, Alkan H and Öztaş Y 1991 Göller bölgesi ve Ispartanin jeolojisi ve stratigrafisi; TPAO arama grubu Rapor No: 3028, Ankara, 321p.

Özpınar Y 2008 Sandıklı (Afyon) yöresinde şabazit ve fillipsit mineralleri içeren tüflerin minerolojik petrografik ve iyon değiştirme özellikleri ve tarımda kullanılması, GB Anadolu, Türkiye; Bull. Min. Res. Exp. 137 27-47.

Öztaş Y 1989 Homa-Akdağ yöresi, Sandıklı-Şuhut kuzeylerinin jeolojisi ve petrol olanakları; TPAO Arşiv Rap. No. 2584, Ankara. 
Richards L A 1954 Diagnosis and improvement of saline and alkali soils, US Department of Agriculture, Handbook 60 160p.

Stumm W and Morgan J J 1981 Aquatic chemistry: Introduction emphasizing equilibria in natural waters; New York, 780p.

Tarcan G 2002 Geothermal water chemistry; Research and Application Center for Geothermal Energy (Jenarum) Summer School, Dokuz Eylul University, İzmir, pp. 230-272.
TS266 2005 Water intended for human consumption; TS 266 Turkish Standards Institution Ankara.

WHO (World Health Organization) 1993 WHO Guidelines for Drinking Water Quality; Health criteria and other supporting information, 2 (Geneva: WHO).

WHO (World Health Organization) 2006 WHO Guidelines for Drinking Water Quality; Guidelines for drinking water quality; First addendum to third edition, 1 Rec. (Geneva: WHO), 494p.

MS received 19 April 2012; revised 5 February 2013; accepted 16 February 2013 